\title{
CIGARETTE BUTTS AND WASTE COFFEE GROUNDS AS ADDITIVES TO BRICK CLAY
}

\author{
Marina Jovanović*, Adnan Mujkanović*, Erna Tutić** \\ * University of Zenica, Faculty of Metallurgy and Technology, Zenica, Bosnia and Herzegovina \\ ${ }^{* *}$ University of Zenica, Polytechnic Faculty, Zenica, Bosnia and Herzegovina \\ corresponding author: Marina Jovanović, e-mail: marina.jovanovic@mtf.unze.ba
}

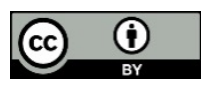

This work is licensed under a

Creative Commons Attribution 4.0

International License
Original scientific paper

Received: March $13^{\text {th }}, 2019$

Accepted: September $18^{\text {th }}, 2019$

HAE-1910

https://doi.org/10.33765/thate.10.1.1

\begin{abstract}
The paper analyses the influence of cigarette butts and waste coffee grounds addition on the properties of the brick clay. The waste materials were added to the clay in amounts of $5 \mathrm{wt} . \%$ and 10 wt.\%. Standard consistency, plasticity, drying and firing behaviour and refractoriness were tested on the clay sample and the samples with wastes additions. Apparent density, apparent porosity, water absorption, strength and thermal conductivity were investigated on the samples fired at 1173 $\mathrm{K}$. Addition of the waste materials improved thermal insulation characteristics and drying shrinkage, while other properties remain within the required limits for brick industry.
\end{abstract}

Keywords: waste utilization, clay, cigarette butts, waste coffee grounds, brick

\section{INTRODUCTION}

Environmentally friendly materials are a very important research field nowadays. Clay bricks, as one of the most frequently used building materials, are a very interesting research material because of their durability, fire resistance, strength, aesthetic characteristics, insulating and many other properties. The main raw material for brick production is clay. However, reserves of the clay are limited, and it is necessary to find the additives that could partially replace the main raw material. Part of the raw material can be replaced by waste material which would lead to savings natural resources and solving problems connected to disposal of certain types of the waste $[1-4]$. In this paper, the effect of adding cigarette butts and coffee waste to the clay was investigated. Cigarette butts and coffee waste are types of organic waste and it is estimated that every year about $4.5 \cdot 10^{12}$ cigarettes are littered in the world [5] and coffee is consumed by around $40 \%$ of the world's population and for many people, especially in the Western countries, drinking coffee is a part of their lifestyle and an everyday habit [6]. The rate of generation of coffee grounds was estimated at an average rate of $3 \mathrm{t}$ of waste per million euros of product sales [7]. The organic additives such as cigarette butts and coffee waste, mixed in the brick clay are burning out during the firing process producing additional amounts of 
energy, and decreasing the total fuel consumption of the industrial furnace [8]. This allows economical use of the energy needed for the firing [7] and shortens the firing time [9]. Also, when the combustible material burns out, it leaves a large fraction of pores within the fired body. The presence of the pores in the materials decreases their thermal conductivity and therefore increases their thermal insulation properties. Also, such produced bricks are lighter compared to the traditional ones [7]. The porous character of these light bricks will increase the quality of structures in terms of heat insulation, thereby reducing heating costs and in turn affecting environment positively. However, mechanical properties of the bricks are negatively affected as a result of physical, chemical and mineralogical alteration [10].

\section{EXPERIMENTAL}

\section{Materials and sample preparation}

The raw materials used in this investigation were clay from "Čavka" deposit situated in the Central Bosnia and Herzegovina near Busovača and cigarette butts and waste coffee grounds from the household. The clay was crushed, dried at $373 \pm 5 \mathrm{~K}$ and sieved through the 1-mm sieve. Only for the purpose of standard consistency and plasticity determination, clay was sieved through the $425-\mu \mathrm{m}$ sieve. The waste coffee grounds were also dried at $373 \pm 5 \mathrm{~K}$. The cigarette butts were dried at $333 \pm 5 \mathrm{~K}$ and ground in electric kitchen chopper for one minute. Five types of mixture were prepared. Their compositions are shown in Table 1.

Table 1. Compositions of prepared mixtures

\begin{tabular}{|c|c|c|c|c|c|}
\hline \multirow{2}{*}{ Material } & \multicolumn{5}{|c|}{ Mixture [wt.\%] } \\
\cline { 2 - 6 } & 1 & 2 & 3 & 4 & 5 \\
\hline Clay & 100 & 95 & 90 & 95 & 90 \\
\hline $\begin{array}{c}\text { Cigarette } \\
\text { butts }\end{array}$ & 0 & 5 & 10 & 0 & 0 \\
\hline $\begin{array}{c}\text { Waste } \\
\text { coffee } \\
\text { grounds }\end{array}$ & 0 & 0 & 0 & 5 & 10 \\
\hline
\end{tabular}

The mixtures were manually kneaded with tap water. In the standard consistency and plasticity tests different amounts of water were added to the clay. For other examinations the water was added according to standard consistency. Three different forms of samples were prepared. Plates of dimensions $300 \times 300$ x $30 \mathrm{~mm}$ were prepared for thermal conductivity determination. For compressive and flexural strength determination the prisms with dimensions of $160 \times 40 \times 40 \mathrm{~mm}$ were prepared. For all other tests, $80 \times 40 \times 14 \mathrm{~mm}$ tiles were prepared. All prepared samples were air-dried for 3 days, followed by drying in drying oven for 24 hours at $303 \mathrm{~K}$ and 24 hours at $373 \mathrm{~K}$. After drying, all the samples (tiles, prisms and plates) were fired at $1173 \mathrm{~K}$. The overall firing process lasted about 21 hours, while the highest temperature was kept for 2 hours.

\section{Methods of characterization}

Chemical composition of clay and waste coffee grounds was determined by the following procedures: loss of ignition was determined by the gravimetric analysis after annealing at $1173 \mathrm{~K}, \mathrm{SiO}_{2}$ content was also determined by gravimetric method, the contents of $\mathrm{Al}_{2} \mathrm{O}_{3}, \mathrm{Fe}_{2} \mathrm{O}_{3}, \mathrm{TiO}_{2}, \mathrm{CaO}, \mathrm{MgO}$, $\mathrm{K}_{2} \mathrm{O}, \mathrm{Na}_{2} \mathrm{O}$ and $\mathrm{MnO}$ were determined after the acidic dissolution at the Atomic Absorption Spectrophotometer (AAS, Perkin Elmer 3100), the contents of $\mathrm{C}$ and $\mathrm{H}$ were determined on a STROHLEIN elemental analysis device by combustion in air steam and deposition on appropriate substrate, and content of $\mathrm{N}$ was determined with a standard Macro-Kjeldahl method. Differential thermal analysis (DTA) and thermogravimetric (TG) analysis were carried out to investigate the raw materials and mixtures behaviour during the thermal treatment. It was done on the NETZSCH thermal analysis instrument STA $409 \mathrm{CD}$ in nitrogen atmosphere up to $1473 \mathrm{~K}$ with heating rate $20 \mathrm{~K} / \mathrm{min}$. Phase composition of the clay was investigated by X-ray diffraction analysis on a Shimadzu diffractometer XRD-6000 with $\mathrm{Cu} \mathrm{K} \alpha$ radiation $(\mathrm{XRD})$, with accelerating voltages of 
$40 \mathrm{kV}$ and current $30 \mathrm{~mA}$, in the range of angles $2-80^{\circ} 2 \theta$ with a step $0.02^{\circ} 2 \theta$ and a dwell time of 0.6 seconds. Standard consistency was determined using Vicat apparatus [11]. Plasticity was determined by the Pfefferkorn plasticity tester [12]. Diagonals were drawn on the prepared tiles and, using a metal device, a circle was drawn with a center at the intersection of the diagonals. The crosssection of the circle with the diagonals gave the reference points which were used to determine drying and firing shrinkage. The equations for the mass loss and shrinkage determination are:

$$
\begin{aligned}
& \text { Mass loss }=\frac{G_{0}-G_{1}}{G_{0}} \cdot 100[\%] \\
& \text { Shrinkage }=\frac{S_{0}-S_{1}}{S_{0}} \cdot 100[\%]
\end{aligned}
$$

where: $G_{0}-$ mass of tile before thermal treatment [g], $G_{1}$ - mass of tile after thermal treatment [g], $S_{0}$ - distance between reference points before thermal treatment [mm], $S_{1}$ distance between reference points after thermal treatment [mm].

To saturate the pore space the tiles were soaked in water to the half of their height for 24 hours. After that, water was added to completely cover the samples and thus left for another 24 hours. The following equations were used to determine water absorption (WA), apparent porosity $\left(P_{a}\right)$ and apparent density $(\gamma)$ :

$$
\begin{gathered}
\mathrm{WA}=\frac{m_{3}-m_{1}}{m_{1}} \cdot 100[\%] \\
\mathrm{P}_{\mathrm{a}}=\frac{m_{3}-m_{1}}{m_{3}-m_{2}} \cdot 100[\%] \\
\gamma=\frac{m_{1}}{m_{3}-m_{2}} \cdot \rho_{w}\left[\mathrm{~g} / \mathrm{cm}^{3}\right]
\end{gathered}
$$

where: $m_{1}-$ mass of dry tile [g], $m_{2}-$ mass of saturated tile in water - hydrostatic weighing [g], $m_{3}-$ mass of saturated tile on air $[\mathrm{g}], \rho_{\mathrm{w}}-$ water density $\left[\mathrm{g} / \mathrm{cm}^{3}\right]$.
Thermal conductivity was tested on the samples with dimensions of $50 \times 50 \times 20 \mathrm{~mm}$ excised from the plates (two samples for the testing) by device Hot Disk TPS 2200 (the product of the Hot Disc AB Company from Gothenburg in Sweden). Refractoriness of the fired samples was investigated in Kryptol furnace according to the standard EN 993-2. Compressive and flexural strength were determined according to the standard EN 1961. The images of crushed surfaces after testing for compressive and flexural strength were taken by the OLYMPUS BX60M binocular optical microscope at $12.5 \mathrm{x}$ magnification.

\section{RESULTS AND DISCUSSION}

Table 2 presents chemical composition of the clay from "Čavka" and waste coffee grounds. Based on the results it can be observed that the examined clay contained $\mathrm{SiO}_{2}$ and $\mathrm{Al}_{2} \mathrm{O}_{3}$ in major quantities and is typical brick clay with higher content of $\mathrm{Fe}_{2} \mathrm{O}_{3}$ and a lower content of $\mathrm{CaO}$. The chemical composition of the waste coffee grounds indicates that it is an organic material which is almost completely transformed into the gaseous phase when heated. Cigarette filter consists essentially of cellulose acetate. Although cigarette butts contain a large number of compounds (including aromatic and heterocyclic amines, carbonylated compounds, phenols, polycyclic aromatic hydrocarbons, carbon and nitrogen oxides and ammonia) [13], many of which are dangerous, research has shown that the concentration values for 11 metals measured in the leaching test on clay bricks manufactured with cigarette butts were insignificant and much lower than the acceptable regulatory limits [14].

Mineralogical examination based on X-ray diffraction analysis, presented in the Figure 1, revealed the presence of quartz, ilite, kaolinite, clinochlor and anorthite in the clay sample. Such composition is typical for the central Bosnia's clays [15]. 
Table 2. Chemical composition of the clay and the waste coffee grounds

\begin{tabular}{|c|c|c|}
\hline \multirow{2}{*}{ Component } & \multicolumn{2}{|c|}{ Chemical composition [\%] } \\
\cline { 2 - 3 } & Clay & $\begin{array}{c}\text { Waste coffee } \\
\text { grounds }\end{array}$ \\
\hline $\mathrm{SiO}_{2}$ & 54.1 & 0.08 \\
\hline $\mathrm{Al}_{2} \mathrm{O}_{3}$ & 19.1 & $<0.01$ \\
\hline $\mathrm{Fe}_{2} \mathrm{O}_{3}$ & 10.2 & 0.01 \\
\hline $\mathrm{TiO}_{2}$ & 1.5 & 0.25 \\
\hline $\mathrm{CaO}$ & 0.36 & 0.78 \\
\hline $\mathrm{MgO}$ & 2.82 & 0.17 \\
\hline $\mathrm{K}_{2} \mathrm{O}$ & 3.51 & 0.47 \\
\hline $\mathrm{Na}_{2} \mathrm{O}$ & 1.15 & 0.01 \\
\hline $\mathrm{MnO}$ & 0.14 & $<0.01$ \\
\hline $\mathrm{P}_{2} \mathrm{O}_{5}$ & 0.183 & 0.206 \\
\hline $\mathrm{LOI}$ & 6.57 & 98.7 \\
\hline $\mathrm{C}$ & - & 52.8 \\
\hline $\mathrm{H}$ & - & 8.54 \\
\hline $\mathrm{N}$ & - & 2.52 \\
\hline
\end{tabular}

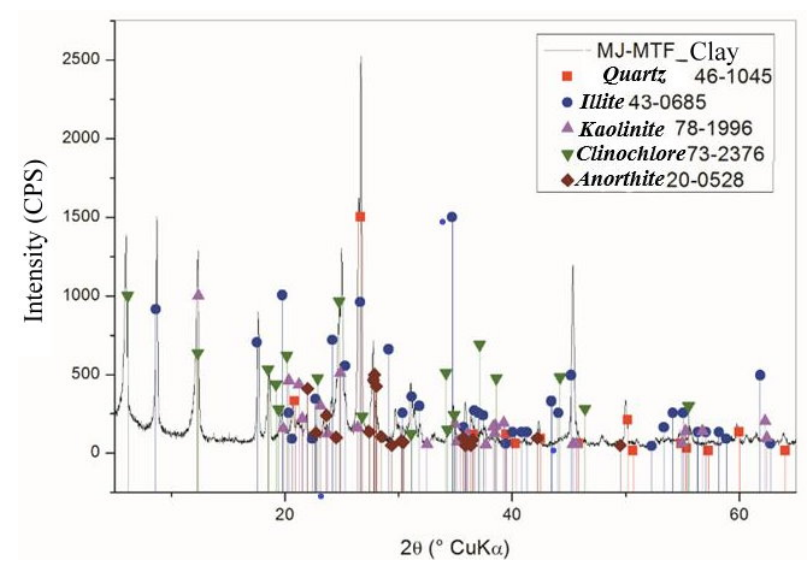

Figure 1. Phase composition of the " $\check{C} a v k a$ " clay

Figure 2 shows DTA/TG/DTG curves for the clay. Mass loss obtained by thermogravimetric analysis is well-matched with loss on ignition in chemical analysis. Clay lost mass in a few steps indicating a greater number of minerals. The first significant loss occurs up to the temperature of $623 \mathrm{~K}$ in three steps. On DTA curve followed by two endothermic peaks at about $433 \mathrm{~K}$ and $573 \mathrm{~K}$, corresponding to the loss of adsorbed and zeolite water from illite, chlorite, limonite and goethite [16 - 23].

The content of $\mathrm{K}_{2} \mathrm{O}$ in chemical analysis is indicative of the amount of illite [21]. The presence of kaolinite and illite, identified by
XRD analysis, is confirmed by mild endothermic change on DTA curve and mass loss between 773 and $873 \mathrm{~K}$ on TG curve and mild change on DTG curve [16, 17, 24, 25]. DTA curves of cigarette butts and waste coffee grounds show board exothermic changes corresponding to decomposition of organic components. The decomposition of cigarette butts occurs mostly below $673 \mathrm{~K}$ (Figure 3a) in one step, which means that it mainly consists of a single substance, while the decomposition of the waste coffee grounds occurs mostly below $800 \mathrm{~K}$ (Figure $3 \mathrm{~b}$ ) in two main steps, which points to a more complex composition of waste coffee grounds. The mass loss of waste coffee grounds in thermogravimetry is lower than the loss of ignition, but the test conditions should be considered. Thermogravimetry was made in a nitrogen atmosphere, so there was no complete combustion of the substance as in the chemical analysis.

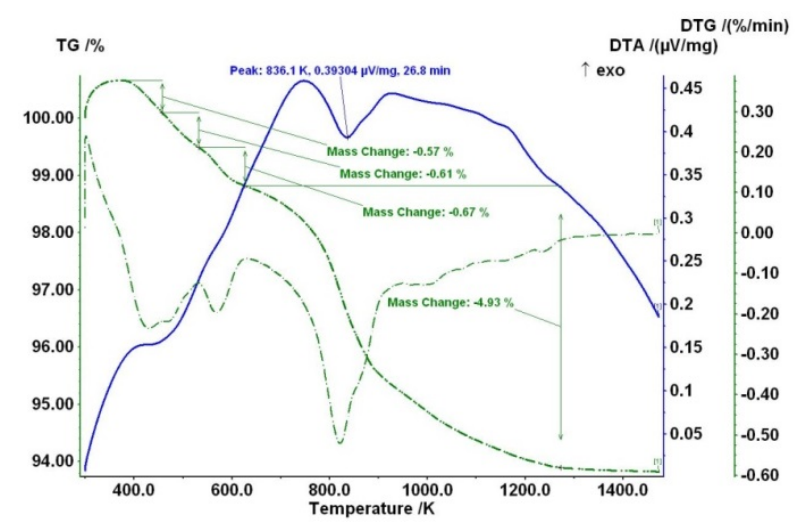

Figure 2. DTA/TG/DTG of the " $\check{C} a v k a$ ” clay

The results of the standard consistency and Pfefferkorn plasticity tests are given in Table 3. Table 4 presents the results of mass loss and shrinkage on drying and firing. The results of the Pfefferkorn plasticity tests indicate that the increase in the additives amounts leads to increasing the amount of water required to reach $30 \%$ height contraction of the test body. So, it might be concluded that the addition of waste coffee grounds and cigarette butts makes the clay more plastic. However, the Pfefferkorn method determines raw material plasticity as water content and not as the resistance to penetration or plastic deformation. 


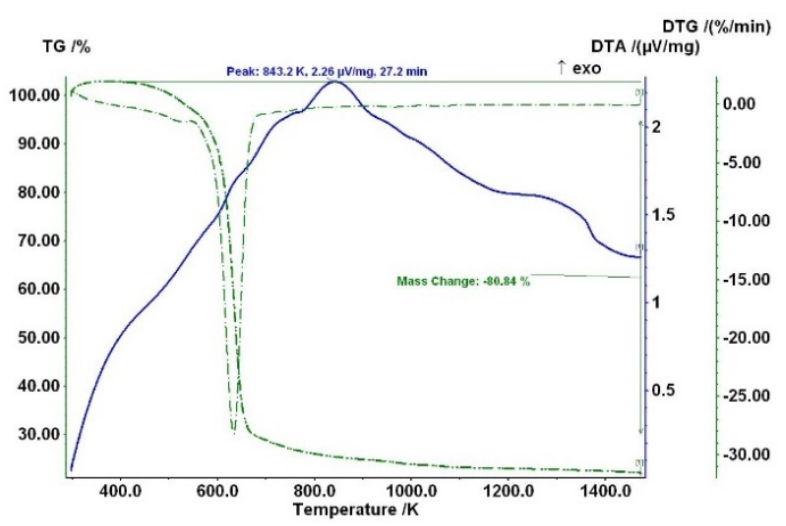

a)



b)

Figure 3. DTA/TG/DTG of cigarette butts (a) and waste coffee grounds (b)

Table 3. Standard consistency and plasticity

\begin{tabular}{|c|c|c|c|c|}
\hline \multirow{2}{*}{$\begin{array}{c}\text { Additive } \\
{[\%]}\end{array}$} & \multicolumn{2}{|c|}{$\begin{array}{c}\text { Standard } \\
\text { consistency [\%] }\end{array}$} & \multicolumn{2}{c|}{$\begin{array}{c}\text { Pfefferkorn } \\
\text { plasicity [\%] }\end{array}$} \\
\cline { 2 - 5 } & $\begin{array}{c}\text { Cigarette } \\
\text { butts }\end{array}$ & $\begin{array}{c}\text { Waste } \\
\text { coffee } \\
\text { grounds }\end{array}$ & $\begin{array}{c}\text { Cigarette } \\
\text { butts }\end{array}$ & $\begin{array}{c}\text { Waste } \\
\text { coffee } \\
\text { grounds }\end{array}$ \\
\hline 0 & 25.7 & 25.7 & 25.51 & 25.51 \\
\hline 5 & 30.4 & 28.8 & 33.0 & 27.55 \\
\hline 10 & 34.0 & 32.4 & 40.78 & 30.32 \\
\hline
\end{tabular}

It should be borne in mind that particles of additives used are highly porous (Figure 4) and absorb a high amount of water leaving less water available for clay particles lubrication which is decisive for clay plasticity. The effect of organic residues on drying shrinkage is explained in the same way. The porous and absorbent nature of the additives particles and fibres stabilizes the drying behaviour of the clay despite the increase in water demand with the addition of organic residues. In clay mixture without additives, the distance between the particles is reduced as water molecules leave the clay during drying process, so that the clay body undergoes significant shrinkage. On the other hand, clay mixtures containing porous particles and fibres lose water during drying process, but a substantial part of evaporated water is contained in particles of additives. This results in decreasing the shrinkage by increasing the percentage of the additives (Table 4) and it is a very favourable effect as it reduces clay sensitivity on drying process and possibility of cracking. In this way it is possible to reduce drying time and save energy.

Table 5 presents effect of the waste content on water absorption and apparent porosity and density. In Table 6, flexural and compressive strength are presented, and in Table 7 thermal conductivity and refractoriness.

Table 4. Mass loss and shrinkage

\begin{tabular}{|c|c|c|c|c|c|c|c|c|}
\hline \multirow{2}{*}{$\begin{array}{c}\text { Additive } \\
{[\%]}\end{array}$} & \multicolumn{4}{|c|}{ Mass loss [\%] } & \multicolumn{4}{c|}{ Shrinkage [\%] } \\
\cline { 2 - 9 } & $\begin{array}{c}\text { Cigarette } \\
\text { butts }\end{array}$ & $\begin{array}{c}\text { Waste } \\
\text { coffee } \\
\text { grounds }\end{array}$ & $\begin{array}{c}\text { Cigarette } \\
\text { butts }\end{array}$ & $\begin{array}{c}\text { Waste } \\
\text { coffee } \\
\text { grounds }\end{array}$ & $\begin{array}{c}\text { Cigarette } \\
\text { butts }\end{array}$ & $\begin{array}{c}\text { Waste } \\
\text { coffee } \\
\text { grounds }\end{array}$ & $\begin{array}{c}\text { Cigarette } \\
\text { butts }\end{array}$ & $\begin{array}{c}\text { Waste } \\
\text { coffee } \\
\text { grounds }\end{array}$ \\
\hline 0 & 20.60 & 20.60 & 6.33 & 6.33 & 4.73 & 4.73 & 1.62 & 1.62 \\
\hline 5 & 23.73 & 22.82 & 10.87 & 10.86 & 3.82 & 4.46 & 0.86 & 0.9 \\
\hline 10 & 26.34 & 24.26 & 15.01 & 14.57 & 3.32 & 3.72 & 0.62 & 0.54 \\
\hline
\end{tabular}



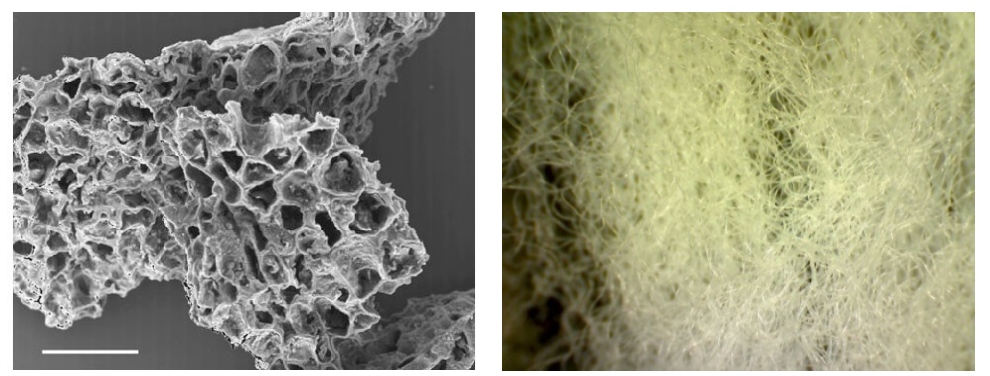

Figure 4. SEM image of waste coffee grounds $(\mathrm{bar}=100 \mu \mathrm{m})$ [26] (left) and filter of cigarette recorded on PCE -MM200 microscope at $12.5 \mathrm{x}$ magnification (right)

Table 5. Apparent porosity, water absorption and apparent density

\begin{tabular}{|c|c|c|c|c|c|c|}
\hline \multirow{2}{*}{$\begin{array}{c}\text { Additive } \\
{[\%]}\end{array}$} & \multicolumn{2}{|c|}{ Apparent porosity [\%] } & \multicolumn{2}{|c|}{ Water absorption [\%] } & \multicolumn{2}{|c|}{$\begin{array}{c}\text { Apparent density } \\
{\left[\mathrm{g} / \mathrm{cm}^{3}\right]}\end{array}$} \\
\cline { 2 - 7 } & $\begin{array}{c}\text { Cigarette } \\
\text { butts }\end{array}$ & $\begin{array}{c}\text { Waste } \\
\text { coffee } \\
\text { grounds }\end{array}$ & $\begin{array}{c}\text { Cigarette } \\
\text { butts }\end{array}$ & $\begin{array}{c}\text { Waste } \\
\text { coffee } \\
\text { grounds }\end{array}$ & $\begin{array}{c}\text { Cigarette } \\
\text { butts }\end{array}$ & $\begin{array}{c}\text { Waste } \\
\text { coffee } \\
\text { grounds }\end{array}$ \\
\hline 0 & 27.21 & 27.12 & 15.64 & 15.64 & 1.74 & 1.74 \\
\hline 5 & 36.57 & 34.91 & 25.07 & 23.49 & 1.47 & 1.49 \\
\hline 10 & 42.84 & 42.13 & 33.88 & 31.2 & 1.26 & 1.28 \\
\hline
\end{tabular}

Table 6. Flexural and compressive strength

\begin{tabular}{|c|c|c|c|c|}
\hline \multirow{2}{*}{$\begin{array}{c}\text { Additive } \\
{[\%]}\end{array}$} & \multicolumn{2}{|c|}{$\begin{array}{c}\text { Flexural strength } \\
{[\mathrm{MPa}]}\end{array}$} & \multicolumn{2}{c|}{$\begin{array}{c}\text { Compressive } \\
\text { strength [MPa] }\end{array}$} \\
\cline { 2 - 5 } & $\begin{array}{c}\text { Cigarette } \\
\text { butts }\end{array}$ & $\begin{array}{c}\text { Waste } \\
\text { coffee } \\
\text { grounds }\end{array}$ & $\begin{array}{c}\text { Cigarette } \\
\text { butts }\end{array}$ & $\begin{array}{c}\text { Waste } \\
\text { coffee } \\
\text { grounds }\end{array}$ \\
\hline 0 & 4.2 & 4.2 & 21.1 & 21.1 \\
\hline 5 & 2.5 & 2.7 & 10.7 & 12.8 \\
\hline 10 & 1.6 & 2.2 & 4.7 & 5.5 \\
\hline
\end{tabular}

Table 7. Thermal conductivity and refractoriness

\begin{tabular}{|c|c|c|c|c|}
\hline \multirow{2}{*}{$\begin{array}{c}\text { Additive } \\
{[\%]}\end{array}$} & \multicolumn{2}{|c|}{$\begin{array}{c}\text { Thermal } \\
\text { conductivity } \\
{[\mathrm{W} / \mathrm{mK}]}\end{array}$} & \multicolumn{2}{c|}{ Refractoriness [K] } \\
\cline { 2 - 5 } & $\begin{array}{c}\text { Cigarette } \\
\text { butts }\end{array}$ & $\begin{array}{c}\text { Waste } \\
\text { coffee } \\
\text { grounds }\end{array}$ & $\begin{array}{c}\text { Cigarette } \\
\text { butts }\end{array}$ & $\begin{array}{c}\text { Waste } \\
\text { coffee } \\
\text { grounds }\end{array}$ \\
\hline 0 & 0.5 & 0.5 & 1438 & 1438 \\
\hline 5 & 0.41 & 0.45 & 1398 & 1438 \\
\hline 10 & 0.34 & 0.38 & 1373 & 1398 \\
\hline
\end{tabular}

Increasing the content of the additives increases the mass loss on firing (Table 4), because the additives mainly transform to the gaseous phase in the firing process, creating a porous structure. This porosity decreases apparent density and mechanical strength while increases water absorption (Tables 5 and $6)$. The effect is more pronounced in the mixtures with the cigarette butts. The specimens with a higher porosity are lighter (Figure 5). That can be considered as positive effect for the transport, handling and particularly for the installation of the bricks. Due to the increased porosity, the flexural and compressive strength decrease but are still acceptable according to clay brick requirements [12]. The results shown in Table 7 indicate that the addition of the additives reduces thermal conductivity and slightly decreases refractoriness. Lower thermal conductivity is desirable because it will reduce the energy required for heating and cooling of buildings.



Figure 5. Weight changes of fired tiles 
From optical microscope images in Figure 6 it can be seen that the addition of the cigarette butts changes structure considerably, while the addition of the waste coffee grounds gives porous texture but the structure remains homogeneous. Larger, elongated or eyelash pores and significant inhomogeneity of the structure are observed in the samples with the cigarette butts, which is why the strength of these samples is lower in comparison to the samples with the waste coffee grounds.



Fired clay

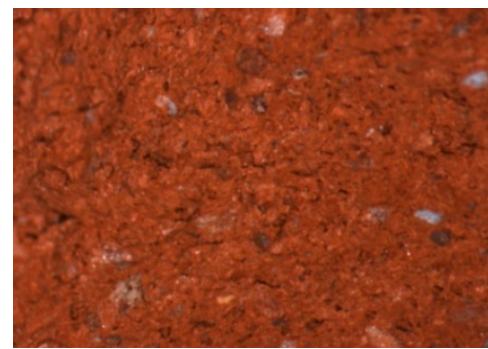

Fired clay with $5 \%$ waste coffee grounds

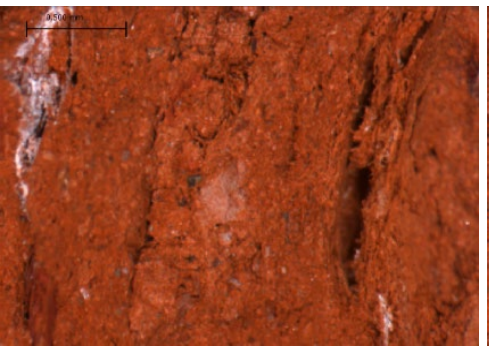

Fired clay with $5 \%$ butts



Fired clay with $10 \%$ butts

Figure 6. Optical microscopy images of fired clay and fired clay with additives

\section{CONCLUSION}

Based on the examination it can be concluded that the cigarette butts and the waste coffee grounds can be added to the brick clay from the "Čavka" deposit in the amount of 10 wt.\%, while mechanical strength remains within the limits prescribed by standards. Moreover, the additives advantageously affect the drying process of the clay and their addition can provide lighter products with improved insulation properties. In this way it is possible to dispose a larger amount of the waste material and thus deal with this growing ecological problem. At the same time, a betterquality product can be obtained that will enable greater energy efficiency in the production and application of clay bricks.

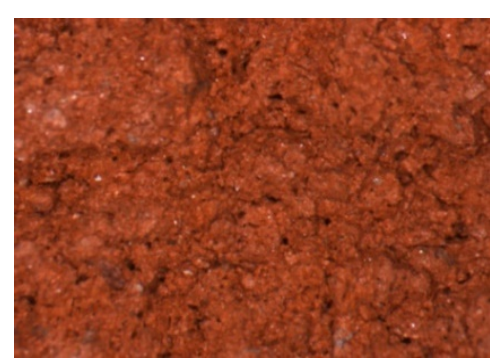

Fired clay with $10 \%$ waste coffee grounds 
[5] E. Slaughter, R.M. Gersberg, K. Watanabe, J. Rudolph, C. Stransky, T.E. Novotny, Toxicity of cigarette butts, and their chemical components, to marine and freshwater fish, https://tobaccocontrol.bmj.com/content/2 0/Suppl_1/i25

Accessed: March 22, 2018.

[6] P. Pohl, E. Stelmach, M. Welna, A. Szymczycha-Madeja, Determination of the elemental composition of coffee using instrumental methods, Food Analytical Methods 6(2013) 2, 598-613.

[7] D. Eliche-Quesada, C. Martínez-García, M.L. Martínez-Cartas, M.T. CotesPalomino, L. Pérez-Villarejo, N. CruzPérez, F.A. Corpas-Iglesias, The use of different forms of waste in the manufacture of ceramic bricks, Applied Clay Science, 52(2011) 3, 270-276.

[8] V. Bánhidi, L.A. Gömze, Improvement of insulation properties of conventional brick products, Materials Science Forum, 589(2008), 1-6.

[9] L. Orešković, Ekološka opeka od otpada, Građevinar 68(2016) 11, 937-941.

[10] N. Phonphuak, Effects of organic residues on physical and mechanical properties of fired clay brick, Proceedings book of $4^{\text {th }}$ International Science, Social Science, Engineering and Energy Conference 2012, Kasem Bundit University, Petchburi, Thailand, December 11 - 14, 2012, 479-485.

http://www.iseec2012.com/Online ISEE C2012/479.pdf

Accessed: February 9, 2017.

[11] V. Tufegdžić, Građevinski materijali, Naučna knjiga, Belgrade, Yugoslavia, 1983.

[12] P. Brzaković, Priručnik za proizvodnju i primenu građevinskih materijala nemetaličnog porekla, Knjiga 2, Orion Art, Belgrade, Serbia, 2000.

[13] M.B. d'Heni Teixeira, M.A.B. Duarte, L.R. Garcez, J.C. Rubim, T.H. Gatti, P.A.Z. Suarez, Process development for cigarette butts recycling into cellulose pulp, Waste Management 60(2017), 140150.
[14] A.A. Kadir, A. Mohajerani, Possible utilization of cigarette butts in lightweight fired clay bricks, International Journal of Civil and Environmental Engineering 2(2008) 9, 137-141.

[15] M. Jovanović, J. Zelić, Ispitivanje i karakterizacija glina srednje Bosne, VIII naučno/stručni simpozijum sa međunarodnim učešćem, „Metalni i nemetalni materijali, proizvodnja osobine - primjena“, ed. S. Muhamedagić, Univerisity of Zenica, Faculty of Metallurgy and Materials Science, Zenica, April 27 - 28, 2010, 194-200.

[16] L. Vaculikova, E. Plevova, Identification of clay minerals and micas in sedimentary rocks, Acta Geodynamica et Geomaterialia 2(2005) 2, 167-175.

[17] D. Antal, T. Húlan, A. Trník, I. Štubňa, J. Ondruška, The influence of texture and firing on thermal and elastic properties of illite-based ceramics, Advanced Materials Research 1126(2015), 53-58.

[18] S. Sufriadin, A. Idrus, S. Pramumijoyo, I.W. Warmada, I. Nur, A. Imai, A.M. Imran, M.S. Kaharuddin, Thermal and infrared studies of garnierite from the Soroako nickeliferous laterite deposit, Sulavesi, Indonesia, Proceedings JCM Makassar 2011, The $36^{\text {th }}$ Indonesian Association of Geophysicists (HAGI) and $40^{\text {th }}$ Indonesian Association of Geologists (IAGI), Makassar, September 26- 29, 2011, 1-10.

[19] S. Balić, Atlas termograma mineralnih materijala, Univerisity of Zenica, Metallurgical institute "Kemal Kapetanović"; Zenica, Bosnia \& Herzegovina, 2007.

[20] G. Jozanikohan, F. Sahabi, G.H. Norouzi; H. Memarian, Thermal analysis: A complementary method to study the Shurijen clay minerals, International Journal of Mining and GeoEngineering 49(2015) 1, 33-45.

[21] S. Ferrari, A.F. Gualtieri, The use of illitic clays in the production of stoneware tile ceramics, Applied Clay Science 32(2006), 73-81. 
[22] A.M Fernandez, V. Timon, J.J. Cubero, D.M. Sanchez-Ledesma, L. GutierrezNebot, J.J. Martinez, C. Romero, M. Labajo, A. Melon, I. Barrios, Comprehensive characterization of palygorskite from Spain based on experimental techniques and theoretical DFT studies, Informes Técnicos Ciemat, 2013.

https://inis.iaea.org/collection/NCLColle ctionStore/_Public/44/122/44122381.pdf $? \mathrm{r}=1 \& \mathrm{r}=1$

Accessed: June 20, 2019.

[23] B. Davarcioglu, Spectaral characterization of non-clay minerals found in the clays (Central Anatolian Turkey), International Journal of the Physical Sciences 6(2011) 3, 511-522.

[24] J.H. de Araújo, N.F. da Silva, W. Acchar, U.U. Gomes, Thermal decomposition of illite, Materials Research 7(2004) 2, 359-361.

[25] Š. Csáki, V. Trnovcová, I. Štubňa, J. Ondruška, I. Sunitrová, L. Vozár, P. Dobroň, AC conductivity of an illitic clay with zeolite addition after firing at different temperatures, Thermophysics 2017: $22^{\text {nd }}$ International meeting of thermophysics 2017 and $4^{\text {th }}$ Meeting of EnRe 2017, ed. A. Trnik, J. Avsec, I. Medved, Terchova, Slovakia, September 12 - 14, 2017, AIP Conference Proceedings 1866, 040008 (2017); https://doi.org/10.1063/1.4994488

[26] I. Safarik, K. Horska, B. Svobodova, M. Safarikova, Magnetically modified spent coffee grounds for dyes removal, European Food Research and Technology 234(2012) 2, 345-350.

\section{Acknowledgements}

This research has been financed by the Ministry of Education and Science of Federation of Bosnia and Herzegovina in the frame of Project "Use of waste materials in clay brick industry". 